\title{
Diagnosis of the pathologies of a bridge, section: Champotón Bridge
}

\section{Diagnóstico de las patologías de un puente, tramo: Puente Champotón}

\author{
BARRERA-LAO, Francisco Javier†๋*, CANUL TURRIZA, Román Alejandro, CRUZ-Y-CRUZ, \\ Andrea del Rosario and GUTIÉRREZ-GONZÁLEZ, Julio Antonio
}

Universidad Autónoma de Campeche, Faculty of Engineering, Mexico.

ID $1^{\text {st }}$ Author: Francisco Javier, Barrera-Lao / ORC ID: 0000-0001-5144-8305

ID $1^{\text {st }}$ Co-author: Román Alejandro, Canul-Turriza / ORC ID: 0000-0003-2081-9913, CVU CONACYT: 546727

ID $2^{\text {nd }}$ Co-author: Andrea del Rosario, Cruz-Y-Cruz / ORC ID: 0000-0001-8861-1276

ID $3^{\text {rd }}$ Co-author: Julio Antonio, Gutiérrez-González / ORC ID: 0000-0002-4813-3828

DOI: $10.35429 / J A D .2020 .11 .4 .20 .28$

Received January 20, 2020; Accepted June 30, 2020

\begin{abstract}
Objective: The present work seeks to expose the current pathological samples in the Champotón bridge, using its own methodology. Methods: It consists of an initial determination on the investigations in the structure and finishes. A non-destructive study of the property was carried out, through an eminently field study, in a qualitative, quantitative, descriptive and longitudinal way, first carrying out a visual inspection, preparing a photographic record, determining a diagnosis that would allow us to information on the object of study, an analysis of the deteriorations found, make a catalog of bridge factories to know the types of design materials, an own evaluation and finally, the most appropriate maintenance plans and proposed criteria were updated with their symbols correspondent. Conclusions. When carrying out a detailed visual inspection of the existing pathologies of the bridge, it is concluded that it requires constant routine maintenance and the pathologies found demand a short-term preventive rehabilitation, in order to prevent further progress and generate probable damages.
\end{abstract}

Approach, Concrete structure, Scour

\begin{abstract}
Resumen
Objetivo: El presente trabajo busca exponer las muestras patológicas actuales en el puente Champotón, ubicado en la localidad del mismo nombre, mediante una metodología propia. Métodos: Consiste en una determinación inicial sobre las investigaciones en la estructura y acabados. Se realizó un estudio no destructivo del inmueble, a través de un estudio eminentemente de campo, en forma cualitativa, cuantitativa, descriptiva y longitudinal, efectuando primeramente una inspección visual, elaborando para ello, un registro fotográfico, determinación de un diagnóstico que nos permitiera obtener información del objeto de estudio, un análisis de los deterioros encontrados, efectuar un catálogo de fábricas del puente para conocer los tipos de materiales de diseño, una evaluación propia y por último, se actualizaron los planos y criterios propuestos de mantenimiento más adecuados con su simbología correspondiente. Conclusiones. Se pudo realizar una inspección visual detallada de las patologías existentes en el puente Champotón, que incluyó toda la información recolectada en trabajo de campo, a partir del cual, el puente requiere un mantenimiento rutinario constante y las patologías encontradas requieren una rehabilitación preventiva a corto plazo, con el fin de evitar que sigan avanzando y genere probables afectaciones
\end{abstract}

Aproche, Estructura de hormigón, Socavación

Citation: BARRERA-LAO, Francisco Javier, CANUL TURRIZA, Román Alejandro, CRUZ-Y-CRUZ, Andrea del Rosario and GUTIÉRREZ-GONZÁLEZ, Julio Antonio. Diagnosis of the pathologies of a bridge, section: Champotón Bridge. Journal Architecture and Design. 2020. 4-11:20-28.

\footnotetext{
* Correspondence to Author (Email: fjbarrer@uacam.mx)

$\uparrow$ Researcher contributing as first author.
} 


\section{Introduction}

Bridges, such as the Champotón bridge (see figure 1), are structures built in order to allow the passage, above all, of vehicles with different capacities through areas of difficult access and safely, they are built of different materials, either be it in steel, concrete or wood.

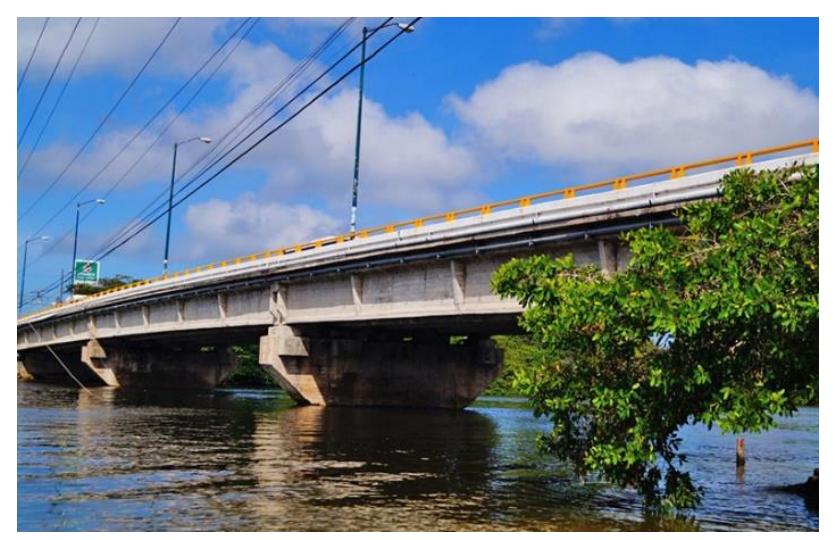

Figure 1 Photograph of the Champotón Bridge. Panoramic view of the bridge, from the north-south point Source: own (2019)

The continuous use of these bridges, climatic factors, settlement movements, seismic movements and the age of their structures, are the cause of pathologies that appear over time that affect their physical state and their operating condition, generating insecurity for Those who make use of these, therefore, require inspections for a continuous scheduled periodic maintenance that allows to evaluate their physical condition and thus determine if they require any type of intervention to keep them in good condition and thus fulfill the function for which they have been built.

In this regard, Moldovan, Lonut, Figuereido, Eloi and Barata Marques, Manuel (2013), affirm that the maintenance of bridge structures is a challenge, even more so when they are in service conditions, additionally, due to the great variety structural systems, which currently range from reinforced or prestressed concrete bridges, as well as composite, steel, cable-stayed, suspended and masonry arch bridges, makes each of these types of structures behave differently, suffering different types of deterioration and therefore, generate different maintenance needs.
Therefore, visual inspections become one of the best alternatives to evaluate the conditions of the bridges, as Masoumi, F.; Akgül, F. and Mehrabzadeh, A. (2013) "visual inspections are one of the most important parts of a bridge management system, they are carried out using non-destructive evaluation methods, which can be used as a tool for verification of the structural conditions of the bridges". Similarly, Adnan, Azlan (2006), presents a non-destructive test method to evaluate the condition of bridges in comparison with the visual inspection that is constantly used; In this, it is stated that although the condition classifications are all qualitative in nature and are defined mainly as sets of visual indicators in routine inspection, non-destructive tests are more quantitative and have great potential to determine damages within the structure that are not visible. For the purpose of this study, the priority was to determine the strength of the bridge through non-destructive tests and thus establish the correlation between the visual inspection qualification and the results of these tests, through an intelligent classification system that combines both the Non-destructive test data such as the visual inspection qualification, generating more efficient and detailed results, in accordance with the above, the visual inspection and evaluation of bridges, is a highly relevant task that requires meticulous and methodical processes. In addition, interest in investigating the status of pedestrian bridges, and the way to keep them in good condition for use, is not only an issue of relevance in the country, internationally there are also investigations on the subject, one of these it is, for example, the one carried out in Spain by the authors Rodríguez, Soledad; et al, (2014), taking into account that in this country a considerable amount of bridges are built in wood and their service time had exceeded their useful life, being necessary an evaluation of the structural state of the same, for this reason the Researchers developed a methodology for inspection, evaluation and diagnosis of the state of bridges, through visual inspection, detection of rotting through the use of equipment, estimation of mechanical properties and static load tests and dynamic analysis to determine the natural frequencies of vibration. 
The foregoing makes it possible to understand that conducting pathology evaluations on pedestrian bridges is a task that can be carried out relatively easily and efficiently, without the need to use complicated methodologies, but rather, through visual inspections, with formats For the recording of detailed information and supported by photographic records, effective diagnoses of the state of the elements that make up the bridge structures can be made, since as stated by Bader, James (2018) "they are particularly useful methods for evaluating bridges in service, since these can remain intact and open to traffic during the inspection and evaluation period".

\section{General Background}

\section{History}

The town of Champotón (its etymology comes from the Mayan language Chakán sabana and Putum, which is a modification of the Petén region or region, meaning "region or region of the savannah"), was founded by the Itzáes, one of the most important lineages of the Mayans when they left Chichén-Itzá, around the year 700 of our era and returned to their native Chichén-Itzá 280 years later. In 1194, when the Confederation of Mazapán was dissolved, which was an alliance between the main Mayan cities, Champotón became the capital of the Chakán-Putún chiefdom or region of the savannah. The first Spanish explorers arrived and found a fatal defeat against the "aborigines", for this place was always named by them with the name of "Costa Bahía de la Mala Pelea". In 1538, Francisco de Montejo El Mozo, founded the Villa de San Pedro Champotón. The municipality of Champotón was thus declared on December 7, 1915, forming one of the 8 (eight) free municipalities of the new state of Campeche, on December 7, 1957 the title of city was granted to its municipal seat.

\section{Orography}

The topographic relief is flat with small undulations that favor the formation of part of the valleys, such as Yohaltún and Edzná, the latter extending to the municipality of Campeche. The average altitude is 27 meters above sea level, from the town of Seybaplaya the Sierra Alta starts, which, on its way along the coast, forms a large cliff with a point known as "El Morro". From Seybaplaya there is also a mountain range called Sierra Seybaplaya in the direction of the Chenes region where there is a flat pronunciation called Meseta de Zoh Laguna; From north to south, the municipality of Champotón has small hills no greater than 30 meters high, in the central part is the plain of the Edzná Valley.

\section{Hydrography}

The Champotón river is located in the municipality, which is navigable with boats of up to 15 tons, from Canasayab to the town of Champotón, in an extension of 35 kilometers, that is, most of the 47 kilometers that measure its total length. Its basin is 6,080 square kilometers and its annual runoff amounts to 885 million cubic meters. We also find the Nayarit $d$ Castellot and Noch lagoons; among the aguadas we have that of Xbacab, Chuiná and Hool.

\section{Weather}

In a strip of 30 kilometers that starts from the coast of the municipality of Champotón, towards the north (part of Campeche and the north center of Calakmul), the climate is warm subhumid with an average annual temperature of $26^{\circ} \mathrm{C}$. In the south, east and southeast of the municipality, there is the most humid variant of sub-humid climates, with a rain regime in the months of June to September; warm winds from the east and southeast predominate; the maximum temperatures are those of the month of May of around $40^{\circ} \mathrm{C}$ and the minimum ones are those of the month of January with $10^{\circ}$ to $14{ }^{\circ} \mathrm{C}$. 


\section{Macro and Micro Location}

The Champotón bridge is located in the southwest of Mexico, in the municipality of Champotón, Campeche state (see Figure 2); It is located in the Yucatan Peninsula, southeast of the Mexican Republic. In the northern part it borders the municipality of Campeche and Hopelchén, to the east with the municipality of Calakmul, in the south with Escárcega and Carmen, to the east with the municipality of Calakmul and to the west with the municipality of Carmen and the Gulf of Mexico. As for the total territorial area that covers Champotón, it has approx. 6,876.26 square kilometers. (INEGI, 2016), with a population density of 12.07 inhabitants / km2. Politically the state of Campeche is currently divided into thirteen municipalities: Calkiní, Calakmul, Campeche, Candelaria, Dzitbalché, Escárcega, Hecelchakán, Tenabo, Hopelchén, Champotón, Carmen, Palizada and Seybaplaya.

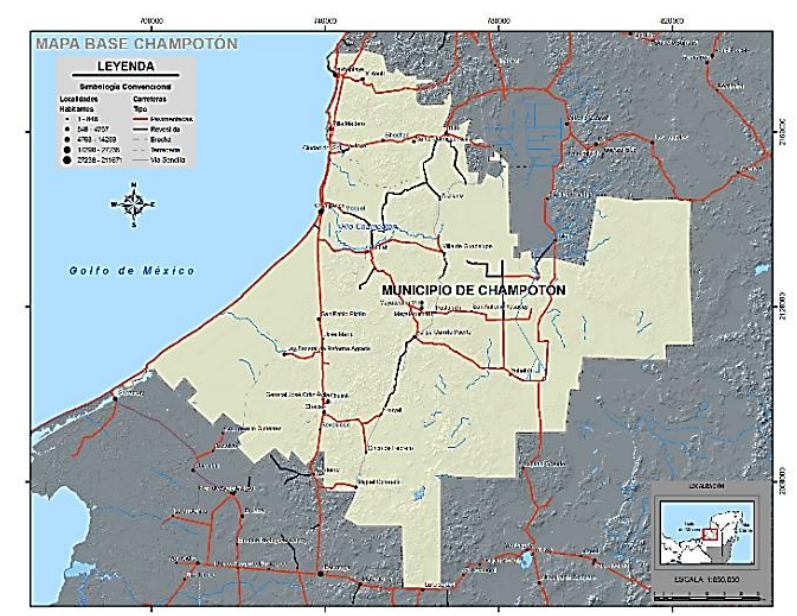

Figure 2 Macro location of the municipality of Champotón

Source: Google Maps (2017). Satelital image

With a population of 83,021 inhabitants according to the 2010 Population and Housing Census (INEGI, 2010), which represents $10.7 \%$ of the state's total. Champotón has a warmhumid climate, with an average temperature of 26 degrees Celsius. Geographically, it is located between meridians $89^{\circ} 32^{\prime}$ 'and $91^{\circ} 08^{\prime}$ west longitude and between parallels $17^{\circ} 49$ 'and 19 - 41' north latitude, it is located to the Northwest $387 \mathrm{kms}$ from the city of Villahermosa; $177 \mathrm{~km}$ southwest of Mérida and $1,127 \mathrm{~km}$ southeast of Mexico City, the municipal seat of Champotón is located with $37.2 \%$ of the population, with respect to the entire municipality.
The city has a maximum altitude of 100 meters. above sea level, with an average height of 27 meters. above mean sea level. The study area, the Champotón bridge, is located on federal highway 180 called Gulf Highway, it is located after the Campeche-Champotón-Hool junction, between the gas station and the Boca del Río spa, both are located at the entrance of the location. (See figure 3).

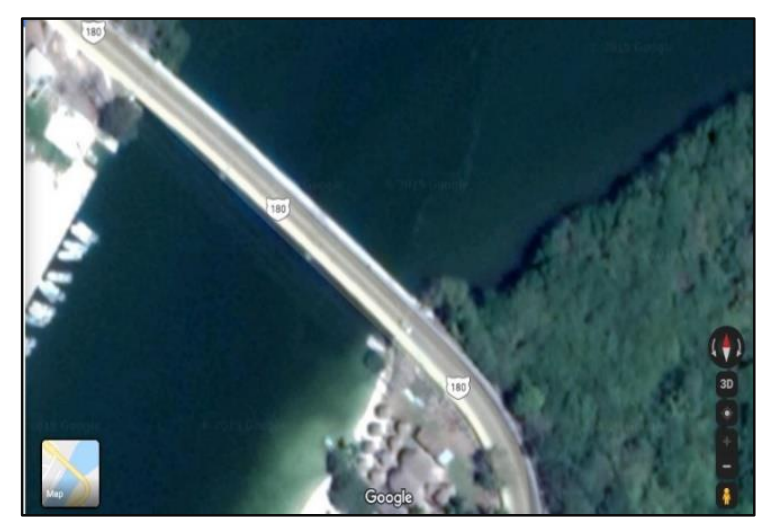

Figure 3 Micro satellite location of the Champotón bridge

Source: Google Earth (2019). Satelital image

\section{Theoretical framework}

According to Ribeiro (2014) and Metha (2008), concrete pathologies can be divided into three main groups: physical, chemical and biological causes: the physical causes of concrete deterioration can be divided into two categories: surface wear (or weight loss) caused by abrasion, erosion and cavitation and cracking at the rate of normal temperature and humidity gradients, salt crystallization pressures in the pores, structural loading and exposure to extreme temperatures, such as freezing or fire. The chemical causes of concrete deterioration are generally due to the presence of chemical substances, which can occur due to: 1) hydrolysis and leaching of the components of the cement paste by pure water, 2 ) ionic changes between aggressive fluids and the paste of cement, 3) reactions causing expandable products, such as expansion by sulfates, alkali-aggregate reaction and corrosion of concrete reinforcement. Biological causes are mainly related to the presence of microorganisms, which promote aggressive corrosive environments to concrete paste and steel, through oxidizing sulfur or sulfide bacteria, which accelerate the deterioration of these structures. 
Enright, Michael P. and. Frangopol, Dan M, (2000) mention for example in their study, that they focus on the reported damage of concrete bridges, especially to bridges located in the state of Colorado (USA), a study on the degradation mechanisms that presents and is applied for various concrete bridges based on information from literature and field studies conducted by the Colorado Department of Transportation. The results showed that the most common source of corrosion damage is water leaking through the board joints. This study generates a significant contribution due to the fact that it refers to the damages presented in a reinforced concrete bridge and the different deterioration mechanisms.

\section{Problem Statement}

Bridges are mostly necessary structures for the movement of vehicles, depending on the type of bridge, its structure behaves in a particular way, suffering different types of deterioration, due to factors such as traffic volume, maximum load weights, as well as exposure to aggressive environmental environments, such as the effects of chlorides, either in a marine environment or de-icing salts, alkali-silica reaction, carbonation and corrosion protection, which requires different maintenance needs at higher frequency.

The Champotón bridge, was originally built of reinforced concrete in 1968 to free the river, had a special design privileged for this type of construction due to the characteristics of the topography of the land in the area where it is located, it is a road called type A2 (two-lane road), in some cases of the section, access to the site was used through an asphalt layer and in another section, it consisted of the placement of reinforced and precast concrete elements, mainly beams to bridge the existing gaps between piers and then a reinforced concrete slab was built on these beams to finally place an asphalt layer as a bearing surface.
The bridge currently has a length of $213 \mathrm{~m}$, which includes two approaches, four beams of five inches each, three concrete slabs with a thickness of $10 \mathrm{~cm}$, two traffic lanes on both sides of 4 meters wide crown, with six meters of a ltura It was maintained by the Secretary of Communications and Transportation (SCT) in November 2016, due to the fact that the bridge had a landslide due to the erosion that was generated by the current of the river, the footings were reinforced, the reinforcement used more than 1650 square meters of stone, and it was finished in the following month. However, the bridge presents certain visible pathologies that must be studied further: drains in poor condition, reinforcement exposed by corrosive processes, undercuts, damage to construction joints, cracks, erosions, rusted materials, paint in an advanced state of deterioration, missing of railings, loose and destroyed sheets, cracked, fissured and / or worn pavements (mainly caused by increased loads, materials with poor quality, buckling, concrete with a lack of vibrating and curing, concreting during extreme ambient temperatures, landslide, failures in the foundations, rooting of trees and shrubs), repair with different materials different from the original ones, require constant maintenance.

The section under study is developed on flat terrain and according to data provided by the General Directorate for Road Conservation, the condition of the bridge's rolling surface and the road is classified from fair to poor, which generates low traffic speeds. increases in vehicle operating costs and high maintenance and road rehabilitation costs. 


\section{Justification}

\section{Offer}

The boardwalk of the City of Champotón, including the Champotón bridge, is part of Route 180 , currently operating with 2 traffic lanes in a crown width of 7.0 meters, a length of $5.10 \mathrm{kms}$, a central median of 4.00 meters wide from the beginning to the Moch-Cohuó Park with a length of 2.47 kilometers and 3.20 meters wide sidewalks, the maximum speed allowed is $40 \mathrm{~km} / \mathrm{hr}$, in the lane from south to north there are shops, restaurants, health establishments, truck station, public market, banking institutions, freezers, cemetery, service station 6979 (gas station) and a park, in the lane from north to south there are riverside fishermen's docks with landing maneuvers for marine species, craft school, street trade, foreign bus stop and one lane in each direction is used for public parking.

\section{Demand}

According to road data published by the SCT in the passage through the city of Champotón (see Table No. 1), 4,615 vehicles circulate daily until 2012, we can note that the vehicular composition of these are $76 \%$ are cars, $8 \%$ are buses and $16 \%$ trucks:

\begin{tabular}{|l|l|l|l|l|l|}
\hline \multicolumn{2}{|c|}{$\mathbf{2 0 0 8}$} & $\mathbf{2 0 0 9}$ & $\mathbf{2 0 1 0}$ & $\mathbf{2 0 1 1}$ & $\mathbf{2 0 1 2}$ \\
\hline Total & 4037 & 4174 & 4316 & 4416 & 4615 \\
\hline
\end{tabular}

Table 1 Total road data published in the passage through the city of Champotón

Source: Ministry of Communications and Transportation (2019)

Interaction and current situation without project. Low traffic speeds are generated on the current route with an average travel time by car of 24 minutes, by bus of 27 minutes and by truck of cargo 32 minutes, increases in vehicle operating costs and high maintenance costs (around 2 million pesos annually) and routine rehabilitation of the current road (around 5 million pesos every 5 years), rebuilding it every 8 years with a total investment of approximately 50 million pesos, at current costs.

\section{Optimization}

Given that for the current total length it is 5.10 $\mathrm{km}$, it generates a vehicular flow with TPDA = 4.615 , with an average rolling speed of $43.6 \mathrm{~km}$ $/ \mathrm{hr}$, on flat terrain and an average growth of the order of 3\%, the main assumptions They are: Extension to 3 meters of the road width of the boardwalk (1.5 meters per side), including the bridge, reducing the width of sidewalks to 1.20 meters and the central median to 1.0 meters in a section of $2.47 \mathrm{~km}$ that goes from Parque Moch Cohuo to the Gas Station, passing by the Champotón bridge. (located at the exit to Escarcega), with road signs.

\section{Methodology}

In most cases, in addition to the detailed inspection in the field, it is necessary to carry out tests aimed at providing information related to the strength and rupture conditions of components of the inspected structure. Following the systematization of Lima (2019), two main components are classified: nondestructive tests and destructive tests.

During non-destructive testing, although it does not always include all of them, we can perform the following tests: Sclerometry; depth of carbonation; Crack control with plaster or glass seals; Ultrasonography; Ganmagraphy; Load Test; Deformation and settlement measurements. For destructive tests, if they allow it to be carried out, we can mention the following tests: Resistance to axial compression in cores removed from the structure; Tensile strength in core removed from the structure; Modulus of deformation of concrete and mortars; Reconstitution of concrete and mortar mix; Specific gravity, permeability and water absorption; Chloride content; Determination of traction in reinforcement samples removed from the structure; Determination of the corrosion potential of reinforcement samples removed from the structure; Compressive strength of individual bricks and blocks; Compressive strength of brick and block prisms. 
Consequently, a series of inspections were carried out on the analyzed element and then a photographic report was made of the pathological manifestations presented, which are compared by attributing values of the degree of damage to the structure. In the Champotón Bridge project, the following studies were carried out:

- Historical research and antecedents of the study area.

- $\quad$ Descriptive study of the area.

- Visual inspection of the study area.

- A survey of the infrastructure (materials used and construction systems).

- Inventory of existing elements in the area.

- A diagnosis of the area and changes inherent to the current traffic was carried out.

- Carry out a quantitative and qualitative investigation of alterations and deterioration (state of conservation of the bridge).

- The degree and type of intervention required was evaluated.

- Rising and updating of architectural plans.

A descriptive study of the environment of the area, to analyze and detail what future activities, contexts and events will be like.

Finally, once the inspections have been carried out, the intervention priority for bridge maintenance is established and they are classified according to their needs, that is, if routine maintenance is required or, on the contrary, a specialized structural diagnosis is required due to situations that are out of the normal behavior of the structures.

\section{Goals}

\section{Overall objective}

Prepare a pathological inspection and evaluation of the Champotón bridge, in order to obtain the current conditions in which they are found, through the application of a visual inspection of the study area and non-destructive methods.

\section{Specific objectives:}

Identify the main characteristics of the bridge, through a documentary review, which serves as a background for the inspection and evaluation of the pathology.

Analyze, through a visual inspection, the physical characteristics of the Champotón bridge, to determine the degree of deterioration of the property at the moment.

\section{Posed hypotheses}

\section{Central hypothesis}

With a better quality of infrastructure that is provided for a good, safe and stable service to citizens, it is necessary to have databases that report the detailed status on a monthly, quarterly, semi-annual or annual basis, by government entities, to keep a strict repair control, and thus accidents can be avoided

\section{Secondary hypotheses}

- $\quad$ The more time passes without intervening the property in major conservation, the greater the degree of deterioration of it.

- The greater the use of the property due to the use of vehicular traffic, the greater the deterioration that occurs in the structure.

- The level of humidity caused by the bridge being in direct contact with sea water and atmospheric factors will increase the structural degree of deterioration of the bridge. 


\section{Results}

Situation with project. Market. Through a field study carried out at the entrance to the city of Champotón, it was recorded that ADT in 2012 was 4,615 vehicles, of which $45 \%$ went to $\mathrm{Cd}$ del Carmen and 55\% to Escárcega; and those arriving from $\mathrm{Cd}$ del Carmen is $54 \%$ and from Escárcega $46 \%$, with this, it is justified to relieve $75 \%$ of the vehicular flow.

\section{Conclusions}

It was possible to carry out a detailed visual inspection of the existing pathologies in the Champotón bridge, which included all the information collected in field work, from which, the bridge requires constant routine maintenance and the pathologies found require preventive rehabilitation to short term, in order to prevent them from continuing to advance and generate probable damages.

It could be determined that the Champotón bridge presents a series of pathologies that minimally affect the elements that make up its structure, however, due to atmospheric agents and its daily service operation, it has generated deterioration, in addition, it is present in the study, related to acts of vandalism, dumping of garbage and substances that little by little affect a constant deterioration and the presence of pathologies.

The main causes, as a result of the visual inspection, it can be concluded that they are related to corrosion, wear and lack of coatings in different parts of the electrical wiring elements, which generate the presence of plant material, organic agents, contamination of the concrete of the structure and pavements, among others.

The Champotón bridge does not present critical conditions that warrant a meticulous intervention according to its pathologies found in the inspections, which shows adequate preventive maintenance of this type of structures.
Elements with less structural damage were obtained, since the beams and the pier system presented non-significant failures and do not represent any risk of collapse or functionality of the bridge.

\section{References}

\section{Books}

Adnan, Azlan; Alih, Sophia and Mirasa, Karim. (2006). Bridge evaluation through nondestructive testing in comparison with visual inspection. In: 6th Asia-Pacific Structural Engineering and Construction Conference, 56 September 2006, p. 42

Lima, H. J. N., Ribeiro, R. S., Palhares, R. A., Melo, G. S. S. A. (2019), "Análisis de manifestaciones patológicas del concreto en viaductos urbanos", Revista ALCONPAT, 9 (2), pp. $247 \quad-\quad 259$, DOI: http://dx.doi.org/10.21041/ra.v9i2.308

Masoumi, F.; Akgül, F. y Mehrabzadeh, A. (2013) Condition Assessment of Reinforced Concrete Bridges by Combined Nondestructive Test Techniques. En: IACSIT International Journal of Engineering and Technology. December, 2013. vol. 5, no. 6, p. 708.

Mehta, P. K; Monteiro, P. J. M. (2008), Concreto: microestrutura, propriedades e materiais. $3^{\circ}$ ed., IBRACON, São Paulo, p. 674.

Moldovan, Ionut; Figueiredo, Elói y Barata Marques, Manuel (2013). Condition Assessment of Bridges: Past, Present and Future. A Complementary Approach. Lisboa: Universidad Católica Editora, 2013. p.2.

Ribeiro, D. V. et al. (2014), Corrosão em estruturas de concreto armado: teoria, controle e métodos de análise. $1^{\circ}$ ed., Campus / Elsevier, Rio de Janeiro, 2014. p. 272. ISBN:978-85352-7547-6.

Rodríguez, Soledad; Vivas, Julio; Vega, Abel y Baño, Vanesa. (2014). Metodología para la inspección, evaluación y diagnóstico mediante técnicas no destructivas del estado estructural de puentes de madera en España. En: Rehabend. Abril - mayo, 2014. Vol. 1, no, 4, p. 29. 


\section{Internet}

Bader, James. Nondestructive Testing and Evaluation of Steel Bridges [en línea]. Maryland: Federal Highway Administration's NDE Validation Center [citado 14 enero, 2018]. http://cee.umd.edu/ ccfu/ref717/BADER_NDE _of_Steel_Bridges.pdf>

Enright, M., \& Frangopol, D. (2000). ASCE Library. Recuperado el 10 de Febrero de 2019, de Survey and Evaluation of Damaged Concrete Bridges: http://ascelibrary.org/doi/abs/10.1061/\%28ASC E\%2910840702\%282000\%295\%3A1\%2831\% 29

Instituto Nacional de Estadística, Geografía e Informática (INEGI, 2010). Catálogo de claves de entidades federativas, municipios $y$ localidades. México: Microrregiones. http://www.microrregiones.gob.mx/catloc/conte nido.aspx?refnac=04002 0001 el 14 de febrero de 2019.

Instituto Nacional de Estadística, Geografía e Informática (INEGI, 2016). Consulta interactiva de datos. México: Registros administrativos.

http://www.inegi.org.mx/est/listacubos/consulta .aspx?p=adm\&c=8 el 10 de febrero de 2019. 